\title{
Role of neuropeptides and amino acids in controlling secretion of hormones from the anterior pituitary gland in pigs
}

\author{
M. J. Estienne ${ }^{1}$, J. M. Harter-Dennis ${ }^{1}$ and C. R. Barb ${ }^{2}$ \\ ${ }^{1}$ Department of Agriculture, University of Maryland Eastern Shore, Princess Anne, MD 21853; \\ and ${ }^{2}$ Animal Physiology Unit, Richard B. Russell Agriculture Research Center, United States \\ Department of Agriculture, Agricultural Research Service, Athens, GA 30613, USA
}

All reproductive processes involve one or more of the protein hormones secreted from the anterior pituitary gland: LH, FSH, prolactin, growth hormone, ACTH and thyroidstimulating hormone (TSH). Primary hormones of reproduction, such as LH and FSH, directly regulate a reproductive activity. For example, LH and FSH stimulate follicular growth and the associated secretion of oestradiol in sows. In contrast, secondary hormones of reproduction such as TSH are permissive and regulate other physiological systems that indirectly, but profoundly, influence reproduction. Reproduction in pigs can be enhanced by developing strategies to alter and control secretion of hormones from the anterior pituitary gland. However, the successful manipulation of adenohypophysial hormone secretion will require a sound understanding of the mechanisms controlling the function of the hypothalamic-pituitary axis. Hypothalamic hormones including GnRH, dopamine, growth hormone-releasing hormone (GHRH), somatostatin, corticotrophin-releasing hormone $(\mathrm{CRH})$ and thyrotrophin-releasing hormone (TRH) are synthesized in perikarya that possess axons that terminate at the median eminence. These hormones are released into the hypothalamo-hypophysial portal vasculature, travel to the anterior pituitary gland and stimulate or inhibit secretion of adenohypophysial hormones. Secretion of hypothalamic hormones is ultimately controlled by a variety of neurotransmitters and neuropeptides, the most studied in swine being the endogenous opioid peptides (EOP) and more recently, the excitatory amino acids (ExAA). In general, EOP inhibit GnRH and hence LH secretion, and this effect involves the central catecholaminergic system. A definitive role for EOP in the modulation of FSH release remains to be determined. EOP stimulate secretion of GHRH and thus growth hormone release, and depending on the animal model studied, EOP exert either stimulatory or inhibitory influences on prolactin secretion. ExAA, working via $N$-methyl-D-aspartate (NMDA) receptors at the central nervous system, stimulate secretion of LH, FSH, growth hormone and prolactin in appropriate animal models. However, in certain situations, an inhibitory effect of ExAA on LH secretion has been demonstrated. The modulation of growth hormone and prolactin secretion by ExAA involves EOP. Research investigating the function of ExAA and EOP in the physiological control of swine reproduction warrants further scrutiny.

\section{Neuroendocrine Control of Adenohypophysial Hormone Secretion}

Hypothalamic hormones, including GnRH, dopamine, GHRH, somatostatin, CRH and TRH, are synthesized in perikarya that possess axons that terminate at the median eminence. These hormones are released into the hypothalamo-hypophysial portal blood vessels, travel to the anterior pituitary gland, and either stimulate or inhibit secretion of adenohypophysial hormones. Anterior pituitary 
gland hormones stimulate target tissues to release hormones and metabolites that in turn modify adenohypophysial hormone secretion via negative and positive feedback mechanisms. Because of space limitations, these intricate feedback loops will not be discussed in this review.

\section{Gonadotrophins}

Administration of $\mathrm{GnRH}$ stimulates $\mathrm{LH}$ secretion, follicular growth and ovulation in prepubertal gilts (Lutz et al., 1985) and hypophysial stalk-transected gilts injected with pregnant mares' serum gonadotrophin (Kraeling et al., 1990). In pigs, as in other mammals, there are two distinct modes of LH secretion that presumably reflect two patterns of GnRH secretion from the central nervous system: (1) episodes of LH release (i.e. pulsatile secretion), the frequency and amplitude of which vary with the reproductive status of the animal, circulating steroidal milieu or with both factors, and (2) preovulatory surge secretion. With regard to gonadotrophins, this review focuses primarily on the neuroendocrine control of pulsatile secretion of LH. The neuroendocrine control of the preovulatory surge of gonadotrophins in pigs has been thoroughly covered in the review by Kraeling et al. (1992).

Kineman et al. (1988) described GnRH-immunostained cell bodies in the medial preoptic area, diagonal band of broca, lateral hypothalamic area, paraventricular nucleus, periventricular zone, suprachiasmatic nucleus and medial basal hypothalamus of ovariectomized and ovary-intact gilts. These perikarya had axons that projected to the median eminence.

Using push-pull cannulae, Leshin et al. (1992) demonstrated that pulsatile release of LH is associated with pulsatile secretion of $\mathrm{GnRH}$, as detected in the vasculature of the anterior pituitary gland of ovariectomized gilts. Disrupting the GnRH signal to the anterior pituitary gland by transection of the hypophysial stalk (Kraeling et al., 1990) or by active or passive immunization against GnRH (Esbenshade et al., 1990) abolished pulsatile release of LH in gilts. Secretion of FSH was also suppressed after immunization against GnRH (Esbenshade et al., 1990).

\section{Prolactin}

Prolactin secretion is tonically inhibited by signals from the central nervous system in pigs. Kraeling et al. (1994) reported high circulating concentrations of prolactin in ovariectomized gilts that were subjected to transection of the hypophysial stalk.

Several studies suggest that dopamine inhibits prolactin secretion in swine. For example, bromocryptine, a dopamine agonist, suppressed prolactin secretion in lactating sows, ovariectomized gilts and ovariectomized gilts that were subjected to transection of the hypophysial stalk (Kraeling et al., 1982, 1994).

In pigs, TRH is a putative prolactin-releasing hormone (Dubreuil et al., 1990; Kraeling et al., 1994). The prolactin response to a TRH challenge was attenuated by bromocryptine treatment in ovariectomized, hypophysial stalk-transected gilts, suggesting that the suppression of dopaminergic pathways is a necessary antecedent to the mechanism by which TRH stimulates prolactin secretion (Kraeling et al., 1994).

\section{Growth hormone}

GHRH stimulates, and somatostatin inhibits, growth hormone secretion in swine (Dubreuil et al., 1990). Immunocytochemical studies have revealed GHRH neurones in the arcuate and ventromedial nuclei, and somatostatin neurones in the periventricular region of gilts (Leshin et al., 1994). GHRH and somatostatin nerve fibres project ventrally into the median eminence.

Active immunization against GHRH abolished episodic secretion of growth hormone in the lactating sow (Armstrong et al., 1990). In contrast, active immunization against somatostatin increased growth hormone secretion in prepubertal boars and gilts (Dubreuil et al., 1989). Disrupting the GHRH signal to the anterior pituitary gland by transection of the hypophysial stalk resulted in a 
loss of pulsatile growth hormone secretion in ovariectomized gilts. Nevertheless, basal growth hormone concentrations were increased, perhaps due to the decreased amount of somatostatin reaching the adenohypophysis (Klindt et al., 1983).

\section{Other anterior pituitary gland hormones}

Relatively little is known about the neuroendocrine control of ACTH and TSH in swine. However, CRH stimulated secretion of cortisol in ovariectomized gilts and in gilts that were ovariectomized and subjected to transection of the hypophysial stalk, presumably by enhancing ACTH secretion (Estienne et al., 1988). Serum concentrations of cortisol before CRH administration were similar for hypophysial stalk-transected and control gilts, indicating that basal secretion of cortisol was maintained in the absence of central inputs (Estienne et al., 1988). Finally, treatment of gilts or lactating sows with TRH enhanced thyroxine secretion, probably as a consequence of increased secretion of TSH (Dubreuil et al., 1990; Barb et al., 1991a).

\section{Catecholamines}

The catecholamines noradrenaline, adrenaline and dopamine are synthesized by neurones within the central nervous system. The conversion of tyrosine to dihydroxyphenylalanine (DOPA) is catalysed by tyrosine hydroxylase and is the rate-limiting step in catecholamine biosynthesis. DOPA is converted to dopamine via the action of aromatic decarboxylase. Dopamine is converted to noradrenaline and then adrenaline via the action of dopamine $\beta$-hydroxylase and phenylethanolamine- $n$-methyltransferase, respectively. Leshin et al. (1996) located tyrosine hydroxylase and dopamine- $\beta$-hydroxylase immunopositive neurones in the hypothalamus of the gilt. It has been hypothesized that in pigs, nerve cells that release catecholamines act as interneurones and participate in the control of secretion of hypothalamic hormones and hence anterior pituitary gland function by EOP and ExAA. Thus, a brief description of the effects of catecholamines on secretion of adenohypophysial hormones is warranted.

Central administration of noradrenaline to adult, gonadectomized miniature pigs had dichotomous effects on LH release (Parvizi and Ellendorff, 1982). Whether noradrenaline stimulated or inhibited secretion of LH depended on the dose administered and specific site of hypothalamic injection.

Reports concerning the effects of dopamine on LH secretion in swine are equivocal. Kraeling et al. (1982) reported that the dopamine agonist bromocryptine decreased serum concentrations of LH in lactating sows. However, Bevers et al. (1983) reported that LH secretion increased in bromocryptine-treated lactating sows. Treatment with bromocryptine had no effect on LH secretion in ovariectomized gilts (Kraeling et al., 1982).

AIMAX (synonym = methallibure) is a derivative of dithiocarbamoylhydrazine and has actions similar to diethyldithiocarbamate, a potent inhibitor of dopamine $\beta$-hydroxylase. Treatment of rats with AIMAX decreased LH secretion, and suppressed noradrenaline synthesis and increased dopamine content in the hypothalamus (Chang et al., 1995). When fed to ovariectomized gilts with (Chang et al., 1993a) or without (Kesner et al., 1987) progesterone replacement therapy, AIMAX suppressed pulsatile gonadotrophin secretion. Moreover, the oestradiol-induced LH surge was abolished and the FSH surge attenuated, in AIMAX-fed, ovariectomized gilts (Kesner et al., 1987). Effects of AIMAX were manifested at the hypothalamus since pituitary responsiveness to exogenously administered GnRH was uncompromised by treatment (Kesner et al., 1987). These findings suggest that catecholamines stimulate both pulsatile and surge secretions of gonadotrophins in swine.

Ingestion of AIMAX had no effect on serum concentrations of growth hormone and prolactin in ovariectomized or ovariectomized, steroid-treated gilts (Kesner et al., 1987; Chang et al., 1993a), and failed to alter pulsatile secretion of growth hormone in boars (D. S. Broughton, M. J. Estienne, J. M. Harter-Dennis, C. R. Barb and T. G. Hartsock, unpublished). AIMAX also had no effect on circulating 
concentrations of the thyroid hormones and cortisol, suggesting that secretion of TSH and ACTH was unaffected in ovariectomized gilts (Kesner et al., 1987).

\section{Endogenous Opioid Peptides}

Endorphins, enkephalins and dynorphins are collectively called EOP and are natural ligands for receptors that also bind opiates. Proopiomelanocortin (POMC) is the precursor for $\beta$-endorphin. Using immunocytochemical techniques, Kineman et al. (1989) located POMC perikarya within the arcuate area in gilts. These cell bodies had fibres that projected to the medial basal hypothalamus, periventricular zone, preoptic area and median eminence.

\section{Effect of EOP and EOP agonists on secretion of anterior pituitary gland hormones}

The role of EOP in controlling LH secretion in pigs has been scrutinized in several thorough reviews (Barb et al., 1991b; Kraeling et al., 1992). In general, treatment of pigs with EOP or their agonists decreased secretion of LH. For example, morphine, an agonist of EOP, suppressed LH secretion when administered to ovariectomized gilts via the lateral cerebral ventricle (Estienne et al., 1990). However, intravenous injections of morphine failed to alter LH secretion in immature boars (Trudeau et al., 1988).

Responses to EOP agonists with regard to FSH secretion have been less consistent. For example, intracerebroventricular injection of morphine suppressed FSH release in ovariectomized gilts in some experiments, but not others (Estienne et al., 1990; Barb et al., 1992a). Morphine inhibited FSH secretion when intravenously administered to immature boars (Trudeau et al., 1988).

Results of several studies suggest that EOP stimulate secretion of prolactin and growth hormone. Intracerebroventricular administration of morphine increased circulating concentrations of prolactin and growth hormone in ovariectomized gilts (Estienne et al., 1990; Barb et al., 1992a).

\section{Effect of EOP antagonists on secretion of anterior pituitary gland hormones}

The classic method for studying the physiological role of an endogenous neuromodulator is to use a selective antagonist to block its effects. Several studies have been conducted in which male and female pigs in various reproductive states were treated with the EOP receptor antagonist naloxone.

Stimulation of LH secretion by treatment with naloxone supports the concept that EOP have a physiological role in inhibiting gonadotrophin secretion. Intravenous treatment with naloxone increased LH secretion in luteal phase, but not follicular phase, gilts (Barb et al., 1986a). Injections of naloxone also increased serum concentrations of LH in lactating sows (Barb et al., 1986b; Mattioli et al., 1986; De Rensis et al., 1993).

Treatment with naloxone stimulated LH release in ovariectomized gilts only if the animals were treated with exogenous progesterone (Barb et al., 1986a, 1988). In contrast, naloxone treatment failed to alter LH release in ovary-intact and ovariectomized, progesterone-treated prepubertal gilts (Barb et al., 1988). However, naloxone increased LH secretion when gilts were ovariectomized before puberty and were treated with progesterone and the EOP antagonist at an age when contemporary gilts had begun to display oestrous cycles (Barb et al., 1988). This study suggests that, in gilts, the development of EOP modulation of LH secretion is a brain maturational process that is independent of gonadal influences. In contrast, naloxone had no effect on LH release in immature boars or barrows, but increased LH secretion in barrows treated with testosterone so as to establish adult concentrations of androgen (Patchev et al., 1987; Trudeau et al., 1989).

Similar to experiments in which equivocal responses to EOP agonists were found, studies examining the effects of naloxone on FSH secretion have yielded conflicting results. For example, naloxone increased FSH secretion in immature boars (Trudeau et al., 1989) and lactating sows (Barb et al., 1987), but had no effect on FSH release in ovariectomized gilts, or ovariectomized, prepubertal gilts with or without progesterone therapy (Barb et al., 1992a). De Rensis et al. (1993) reported that 
naloxone had no effect on FSH secretion in postpartum sows. Interestingly, Barb et al. (1992a) also reported that naloxone treatment suppressed FSH secretion in prepubertal gilts and in mature, ovariectomized gilts treated with progesterone.

Changes in LH release without concomitant alterations in FSH secretion and vice versa support the notion that there are separate releasing hormones for the two gonadotrophins in pigs. Alternatively, divergent patterns of $\mathrm{LH}$ and FSH secretion following treatment with EOP agonists and antagonists could be related to circulating concentrations of steroids and gonadal peptides or the existing pattern of GnRH release. Jayes et al. (1997) suggested that high GnRH pulse frequency was more effective in acutely releasing LH than FSH, and inhibits FSH synthesis and secretion. In contrast, low GnRH pulse frequency supports FSH synthesis and release but is not effective in increasing LH concentrations.

Naloxone treatment suppressed secretion of growth hormone (Armstrong et al., 1990; Barb et al., 1991a) and prolactin (Mattioli et al., 1986; Barb et al., 1987) in lactating sows. De Rensis et al. (1993) reported that naloxone treatment suppressed prolactin secretion when administered at day 10 of lactation but not when given during the first $78 \mathrm{~h}$ postpartum.

Naloxone increased prolactin secretion in luteal phase gilts (Barb et al., 1986a) and in mature, ovariectomized, progesterone-treated gilts (Barb et al., 1992a), but had no effect on prolactin release in mature, ovariectomized gilts or ovariectomized, prepubertal gilts with or without progesterone treatment (Barb et al., 1992a). Thus, it appears that EOP exert both stimulatory and inhibitory effects on prolactin secretion in swine.

The effects of naloxone on ACTH and TSH secretion in swine have not been reported. However, naloxone treatment stimulated cortisol secretion in cyclic and ovariectomized gilts (Barb et al., 1986a; Estienne et al., 1988) and inhibited cortisol secretion in lactating sows (Barb et al., 1991a).

\section{Site of action for effects of EOP on adenohypophysial hormone secretion}

The notion that the EOP restraint on gonadotrophin secretion is manifested primarily at the hypothalamus is supported by studies in vitro in which naloxone stimulated GnRH secretion from the hypothalamic-preoptic area collected from gilts (Barb et al., 1994). Moreover, naloxone failed to increase LH secretion in gilts treated with antisera to $\mathrm{GnRH}$ (Chang et al., 1993a). Naloxone had no effect on the LH and FSH response to $\mathrm{GnRH}$ when the EOP receptor antagonist and secretogogue were administered concomitantly in immature boars (Trudeau et al., 1989).

Treatment with naloxone in sows injected with control serum decreased growth hormone concentrations and the frequency of growth hormone pulses to values reported for saline-treated, GHRH-immunized sows (Armstrong et al., 1990). This finding suggests that high circulating concentrations of growth hormone in the lactating sow are primarily due to an opioid-modulated increase in GHRH secretion.

Naloxone-stimulated secretion of cortisol in ovariectomized gilts was abolished by transection of the hypophysial stalk (Estienne et al., 1988). Since serum cortisol concentrations increased in these animals following CRH and ACTH administration, Estienne et al. (1988) concluded that naloxone increased cortisol secretion in swine by acting at the hypothalamus to alter release of $\mathrm{CRH}$ and subsequent $\mathrm{ACTH}$ secretion.

Despite the abundance of evidence suggesting that modulation of anterior pituitary gland hormone secretion by EOP in swine is primarily a consequence of central actions, there may be subtle effects of EOP directly on the adenohypophysis. $\beta$-Endorphin suppressed basal and GnRH-induced LH secretion by pig pituitary cells in vitro (Barb et al., 1990). In contrast, chronic exposure to naloxone increased basal secretion of $\mathrm{LH}$ and enhanced pituitary responsiveness to GnRH (Barb et al., 1990).

\section{Mechanism of action for effects of EOP on adenohypophysial hormone secretion}

Catecholamines stimulate, and EOP inhibit, secretion of GnRH and hence LH in pigs. Several lines of evidence suggest that EOP and catecholamines interact in regulating GnRH secretion (Fig. 1). Anatomical studies have revealed that POMC, tyrosine hydroxylase and dopamine 


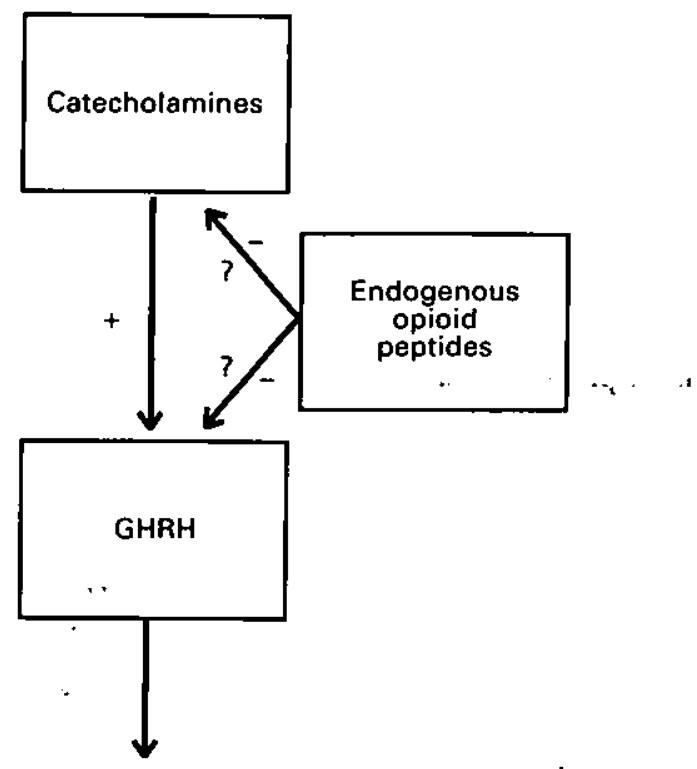

Fig. 1. Possible neuronal pathways by which endogenous opioid peptides inhibit secretion of $\mathrm{GrRH}$, and hence LH, release in swine.

$\beta$-hydroxylase immunopositive neurones are located in the vicinity of $\mathrm{GnRH}$ neurones in the hypothalamus (Kineman et al., 1988, 1989; Leshin et al., 1996).

Treatment with AIMAX abolished naloxone stimulation of LH secretion in ovariectomized, progesterone-treated gilts (Chang et al., 1993a). The prolactin response to naloxone was not attenuated in ovariectomized, progesterone-treated gilts fed AIMAX, suggesting EOP modulation of prolactin secretion is independent of the noradrenaline system (Chang et al., 1993a).

\section{Excitatory Amino Acids}

A group of amino acids that includes glutamate and aspartate has been implicated as the major family of neurotransmitters in the mammalian central nervous system. The ExAA satisfy the main criteria for classification as neurotransmitters, namely: (1) presynaptic localization in specific nerve terminals, (2) specific release by physiological stimuli in concentrations great enough to evoke a postsynaptic response, (3) identity of action (i.e., postsynaptic actions of the naturally occurring transmitter are mimicked by the candidate substance, including response to antagonists), and (4) existence of neuronal mechanisms, such as re-uptake and metabolism, that terminate neurotransmitter action.

Studies in other species have demonstrated that glutamate and aspartate, and receptors for these ExAA, appear in many regions of the brain including the hypothalamus and median eminence. There are several types of receptor that are stimulated by glutamate and these are named according to their selective agonists. Receptor types include $N$-methyl-D-aspartate (NMDA), kainate, and $D, L-$ amino-3-hydroxy-5-methyl-4-isoxazole propionic acid (AMPA) (Petralia and Wenthold, 1996).

\section{Secretion of hormones from the anterior pituitary gland following administration of ExAA}

The ExAA agonist, $N$-methyl-D,L-aspartate (NMA) is a potent activator of the NMDA receptor. The ability of intravenously administered NMA to alter secretion of hormones from the anterior pituitary gland has been confirmed in several experiments in pigs (Table 1). In contrast to the 
Table 1. Effects of intravenous injections of $N$-methyl-D,L-aspartate (NMA) on circulating concentrations of hormones secrèted from the anterior pituitary gland in swine

\begin{tabular}{|c|c|c|c|}
\hline Hormone and model & $\begin{array}{c}\text { Dose of NMA } \\
\text { (mg kg-1 body weight) }\end{array}$ & Result & References \\
\hline \multicolumn{4}{|l|}{ LH } \\
\hline Prepubertal gilts & $\begin{array}{l}1.25,2.5 \text { or } 5.0 \\
10.0\end{array}$ & $\begin{array}{l}\text { No effect } \\
\text { Increased }\end{array}$ & $\begin{array}{l}\text { Estienne et al., } 1995 \\
\text { Estienne } \text { et al., } 1995\end{array}$ \\
\hline Cyclic gilts - luteal phase & 10.0 & Increased & Hurlock et al., 1995 \\
\hline $\begin{array}{l}\text { - follicular phase } \\
\text { Lactating sows }\end{array}$ & $\begin{array}{l}10.0 \\
1.5 \text { or } 3.0\end{array}$ & $\begin{array}{l}\text { No effect } \\
\text { No effect }\end{array}$ & $\begin{array}{l}\text { Hurlock et al., } 1995 \\
\text { Sesti and Britt, } 1992\end{array}$ \\
\hline & 5.0 & Increased & Sesti and Britt, 1992 \\
\hline & 10.0 & Increased & $\begin{array}{l}\text { Sesti and Britt, 1993, } \\
1994\end{array}$ \\
\hline Ovariectomized gilts & 10.0 & $\begin{array}{l}\text { Decreased } \\
\text { Decreased }\end{array}$ & $\begin{array}{l}\text { Barb et al., 1992b } \\
\text { Chang et al., 1993b }\end{array}$ \\
\hline & & Decreased & Hurlock et al., 1995 \\
\hline & & Decreased & Popwell et al., 1996 \\
\hline Ovariectomized, & 10.0 & Increased & Sesti and Britt, 1992 \\
\hline oestradiol-treated gilts & 10.0 & No effect & Barb et al., 1992b \\
\hline $\begin{array}{l}\text { Ovariectomized, } \\
\text { progesterone-treated gilts }\end{array}$ & 10.0 & Decreased & $\begin{array}{l}\text { Barb et al., 1992b; } \\
\text { Chang et al., 1993b }\end{array}$ \\
\hline Boars & $1.25,2.5,5.0$ or 10.0 & No effect & Broughton et al., 1996 \\
\hline Barrows & 2.5 & No effect & Popwell et al., 1996 \\
\hline FSH & & & \\
\hline Lactating sows & 10.0 & Increased & $\begin{array}{l}\text { Sesti and Britt, 1993, } \\
1994\end{array}$ \\
\hline Growth Hormone & & & \\
\hline Prepubertal gilts & $\begin{array}{l}1.25 \text { or } 5.0 \\
2.5 \text { or } 10.0\end{array}$ & $\begin{array}{l}\text { No effect } \\
\text { Increased }\end{array}$ & Estienne et al., 1995 \\
\hline Ovariectomized gilts & 10.0 & lncreased & $\begin{array}{l}\text { Barb et al., 1992b; } \\
\text { Chang et al., 1993b }\end{array}$ \\
\hline $\begin{array}{l}\text { Ovariectomized, } \\
\text { oestradiol-treated gilts }\end{array}$ & 10.0 & Increased & Barb et al., 1992b \\
\hline $\begin{array}{l}\text { Ovariectomized, } \\
\text { progesterone-treated gilts }\end{array}$ & 10.0 & Increased & $\begin{array}{l}\text { Barb et al., 1992b; } \\
\text { Chang et al., 1993b }\end{array}$ \\
\hline Boars & $1.25,2.5,5.0$ or 10.0 & Increased & Broughton et al., 1996 \\
\hline & 2.5 & Increased & Estienne et al., 1996c. \\
\hline Barrows & $\begin{array}{l}1.25 \\
2.5 \text { or } 5.0\end{array}$ & $\begin{array}{l}\text { No effect } \\
\text { Increased }\end{array}$ & $\begin{array}{l}\text { Estienne et al., 1996b } \\
\text { Estienne et al., 1996b }\end{array}$ \\
\hline \multicolumn{4}{|l|}{ Prolactin } \\
\hline Ovariectomized gilts & 10 & Increased & $\begin{array}{l}\text { Barb et al., 1992b; } \\
\text {. Chang et al., 1993b }\end{array}$ \\
\hline $\begin{array}{l}\text { Ovariectomized, } \\
\text { oestradiol-treated gilts }\end{array}$ & 10 & Increased & Barb et al., 1992b \\
\hline $\begin{array}{l}\text { Ovariectomized, } \\
\text { progesterone-treated gilts }\end{array}$ & $\begin{array}{l}10 \\
10\end{array}$ & $\begin{array}{l}\text { No effect } \\
\text { Increased }\end{array}$ & $\begin{array}{l}\text { Barb et al., 1992b } \\
\text { Chang et al., 1993b }\end{array}$ \\
\hline
\end{tabular}

extensive studies on NMDA receptor regulation of adenohypophysial hormone secretion, the role of other ExAA receptors in controlling secretion of anterior pituitary gland hormones has received scant attention.

Effects of ExAA on gonadotrophin secretion. Typically, secretion of LH and FSH is increased by NMA in animal models that are characterized as having suppressed gonadotrophin secretion. For 


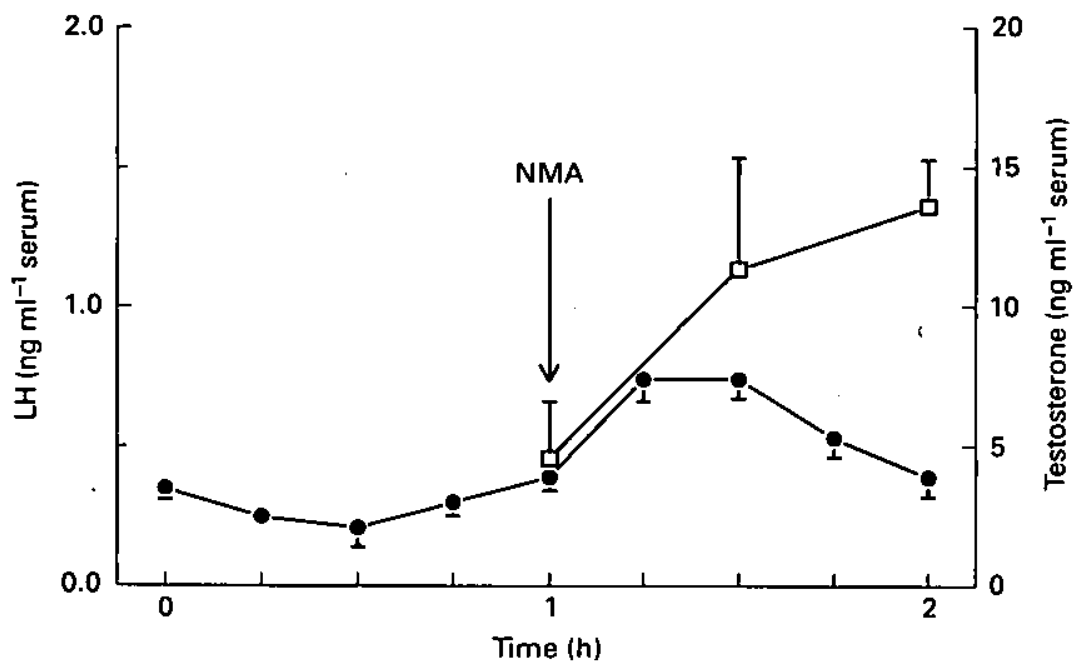

Fig. 2. Serum concentrations of $\mathrm{LH}(\bullet)$ and testosterone $(\square)$ in mature boars receiving an intravenous injection of $N$-methyl-D,L-aspartate (NMA; $10 \mathrm{mg} \mathrm{kg}^{-1}$ body weight). Blood samples were collected at $15 \mathrm{~min}$ intervals for $2 \mathrm{~h}$ and NMA was administered at $1 \mathrm{~h}$ (arrow). All of the samples were analysed for concentrations of $\mathrm{LH}$, and testosterone concentrations were determined in samples collected at 1.0, 1.5 and $2.0 \mathrm{~h}$. Values are means \pm standard errors $(n=5)$. NMA administration resulted in an increase in LH $(P<0.01)$ and testosterone $(P<0.05)$ secretion.

example, NMA stimulated LH release in ovariectomized, oestradiol-treated gilts (Sesti and Britt, 1992), and enhanced secretion of both LH and FSH in lactating sows (Sesti and Britt, 1992, 1993, 1994). NMA stimulated LH release throughout lactation in both multiparous and primiparous sows, while FSH secretion increased when the secretogogue was administered between day 7 and day 21 postpartum in multiparous sows and between day 14 and day 21 postpartum in primiparous sows (Sesti and Britt, 1993, 1994).

Work in our laboratory demonstrated that administration of NMA increased LH secretion in prepubertal gilts (Estienne et al., 1995) and in gilts treated during the luteal, but not follicular, phase of the oestrous cycle (Hurlock et al., 1995). Failure of follicular phase gilts to respond to NMA in that study was perhaps due to oestradiol-induced alterations in pituitary sensitivity to GnRH. Indeed, the response to a $\mathrm{GnRH}$ challenge was compromised in follicular phase compared with luteal phase or ovariectomized gilts (Hurlock et al., 1995).

Broughton et al. (1996) reported that NMA at doses of $1.25-10 \mathrm{mg} \mathrm{kg}^{-1}$ body weight failed to alter $\mathrm{LH}$ release in-immature boars that were approximately 6 months of age. However, we recently demonstrated that NMA, at a dose of $10 \mathrm{mg} \mathrm{kg}^{-1}$ body weight, increased secretion of LH and testosterone in mature boars that were approximately 13 months of age (Fig. 2). These findings are consistent with the concept that, in boars, there is an age-related change in sensitivity of the gonadotrophin response to NMA.

In contrast to the studies showing stimulation of LH secretion by NMA, Barb et al. (1992b) and Chang et al. (1993b) reported that NMA had no effect on LH release in ovariectomized, oestradioltreated gilts and decreased LH secretion in ovariectomized, progesterone-treated gilts. Treatment with NMA also decreased circulating concentrations of LH in ovariectomized gilts (Barb et al., 1992b; Chang et al., 1993b; Hurlock et al., 1995; Popwell et al., 1996). These studies suggest that, in addition to well-documented stimulatory effects, under appropriate conditions, ExAA may also suppress gonadotrophin secretion.

Effect of ExAA on growth hormone secretion. The effects of ExAA on growth hormone secretion, growth performance and carcass quality in domestic animals were summarized by Estienne et al. (1996a). Barb et al. (1996) reported that intravenous administration of aspartate $\left(50-150 \mathrm{mg} \mathrm{kg}^{-1}\right.$ body 
weight) or glutamate (100-150 mg kg-1 body weight) increased serum concentrations of growth hormone in prepubertal gilts. Moreover, infusion of NMA evoked growth hormone release in ovariectomized gilts receiving no treatment or steroid replacement therapy (Barb et al., 1992b; Chang et al., 1993b), prepubertal gilts (Estienne et al., 1995), barrows (Estienne et al., 1996b) and boars (Broughton et al., 1996; Estienne et al., 1996c).

The $D, L$ racemic mixture of NMA has been used in neuroendocrine experiments but no attempt was made to determine which specific isomer was responsible for increasing blood concentrations of adenohypophysial hormones. However, using barrows, we demonstrated that the pure $D$ isomer of NMA, at a dose of $1.25 \mathrm{mg} \mathrm{kg}^{-1}$ body weight, increased serum concentrations of growth hormone in a manner comparable to that which occurs after treatment with the $D, L$ racemic mixture of NMA at a dose of $2.5 \mathrm{mg} \mathrm{kg}^{-1}$ body weight (Estienne et al., 1996b). In contrast, injection of the pure $\mathrm{L}$ isomer of NMA (1.25 $\mathrm{mg} \mathrm{kg}^{-1}$ body weight) did not increase secretion of growth hormone. These results do not preclude the possibility that higher doses of the pure $L$ isomer of NMA may evoke hypersecretion of growth hormone.

Effect of ExAA on secretion of other anterior pituitary gland hormones. Barb et al. (1992b) reported that the injection of NMA increased serum concentrations of prolactin in ovariectomized and ovariectomized, oestradiol-treated gilts, but not in ovariectomized, progesterone-treated gilts. However, in a subsequent study, NMA increased prolactin secretion in both ovariectomized and ovariectomized, progesterone-treated gilts (Chang et al., 1993b).

Circulating concentrations of ACTH and TSH following treatment with NMA have not been reported for swine. However, Barb et al. (1992b), Chang et al. (1993b) and Popwell et al. (1996) demonstrated that NMA increased serum concentrations of cortisol in ovariectomized and ovariectomized, steroid-treated gilts, and barrows, perhaps as a consequence of pituitary release of ACTH.

\section{ExAA-induced secretion of hormones from the adenohypophysis: mechanism of action}

Secretion of adenohypophysial hormones induced by exogenous ExAA is primarily a consequence of action at the central nervous system rather than a direct pituitary effect. Administration of NMA had no effect on serum concentrations of LH in ovariectomized gilts that were passively immunized against $\mathrm{GnRH}$ (Sesti and Britt, 1992). Active immunization against GHRH abolished the ability of NMA to increase circulating concentrations of growth hormone in ovariectomized gilts (Barb et al., 1996). Similarly, NMA-induced increases in growth hormone secretion were abolished by treating barrows with antiserum to GHRH (Estienne et al., 1996b).

Although most of the evidence suggests a central site for the effects of ExAA on release of pituitary hormones, subtle effects of the compounds directly on the anterior pituitary gland cannot be discounted. Studies in vitro demonstrated a positive effect of aspartate and glutamate on growth hormone secretion by pituitary cells collected from prepubertal gilts (Barb et al., 1996). Barb et al. (1993) also reported that NMA stimulated growth hormone release from pituitary cells collected from ovariectomized gilts and gilts in the luteal phase of the oestrous cycle, but not from pituitary cells obtained from gilts in the follicular phase of the oestrous cycle. Treatment with NMA increased LH secretion from pituitary cells collected from ovariectomized, luteal phase and follicular phase gilts (Barb et al., 1993).

Neural loci at which intravenously administered ExAA may act to stimulate release of hypothalamic hormones include the areas of the brain that lack a distinct blood-brain barrier. Price et al. (1981) reported preferential uptake of subcutaneously administered aspartate and glutamate by circumventricular organs of the rat brain. Therefore, exogenously administered ExAA may affect hypothalamic hormone secretion in pigs by influencing function of cell bodies in specific nuclei and(or) nerve terminals in the median eminence. However, these results do not preclude the existence of endogenous ExAA neurotransmission within the blood-brain barrier. 


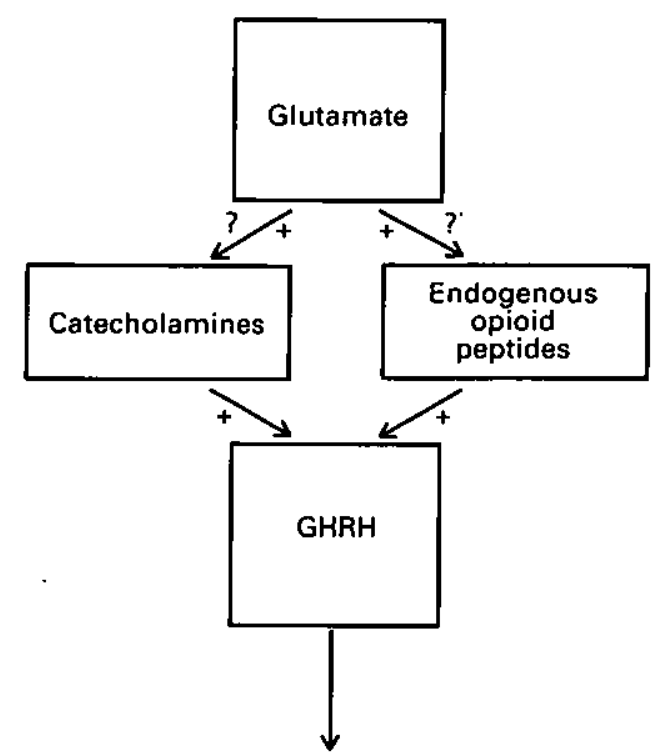

Fig. 3. Possible neuronal pathways by which excitatory amino acids such as glutamate stimulate release of growth hormone-releasing hormone (GHRH), and hence, growth hormone secretion in pigs.

Results from our laboratory are consistent with the concept that stimulation of adenohypophysial hormone secretion (at least growth hormone) by NMA is modulated by NMDA receptors. Treatment of barrows with ketamine hydrochloride, a noncompetitive NMDA receptor antagonist, attenuated the growth hormone response to NMA (Estienne et al., 1996b).

It is unclear whether ExAA affect hypothalamic hormone secretion by a direct effect on neurones that secrete these hormones or indirectly through effects on interneurones (Fig. 3). As previously mentioned, drugs with opiate-like activity alter adenohypophysial hormone secretion in swine and it has been hypothesized that NMA-induced effects on secretion of LH, growth hormone and prolactin are mediated through EOP. In support of this hypothesis, administration of naloxone attenuated the growth hormone and prolactin responses to NMA in ovariectomized and ovariectomized, progesterone-treated gilts (Chang ef al;; 1993b). In that study, however, responsiveness to NMA with regard to LH secretion was unaffected by naloxone.

We recently conducted an experiment to test the hypothesis that NMA-induced growth hormone secretion is modulated by catecholamine neurotransmission (D. S. Broughton, M. J. Estienne, J. M. Harter-Dennis, C. R. Barb and T. G. Hartsock, unpublished). Boars were fed a daily ration containing 0 or $125 \mathrm{mg}$ AIMAX daily for 9 days ( $n=5$ per treatment). On day 8 , blood samples were collected every $15 \mathrm{~min}$ for $8 \mathrm{~h}$. Four and six hours after sampling was initiated, boars allowed each ration received intravenous injections of NMA $\left(2.5 \mathrm{mg} \mathrm{kg}^{-1}\right.$ body weight) or saline. The next day the experiment was repeated, but boars that previously received NMA were administered saline and vice versa. Before NMA or saline injections, mean serum growth hormone concentrations and the frequency and amplitude of growth hormone pulses were similar for AIMAX and control groups. Injections of NMA significantly increased mean serum growth hormone concentrations and growth hormone pulse amplitude in both groups in a similar fashion (Fig. 4). Treatment with NMA did not alter frequency of growth hormone pulses. These results suggest that in boars, catecholamines: (1) do not play a significant role in modulating pulsatile secretion of growth hormone, and (2) do not mediate the effects of NMA on growth hormone secretion. 

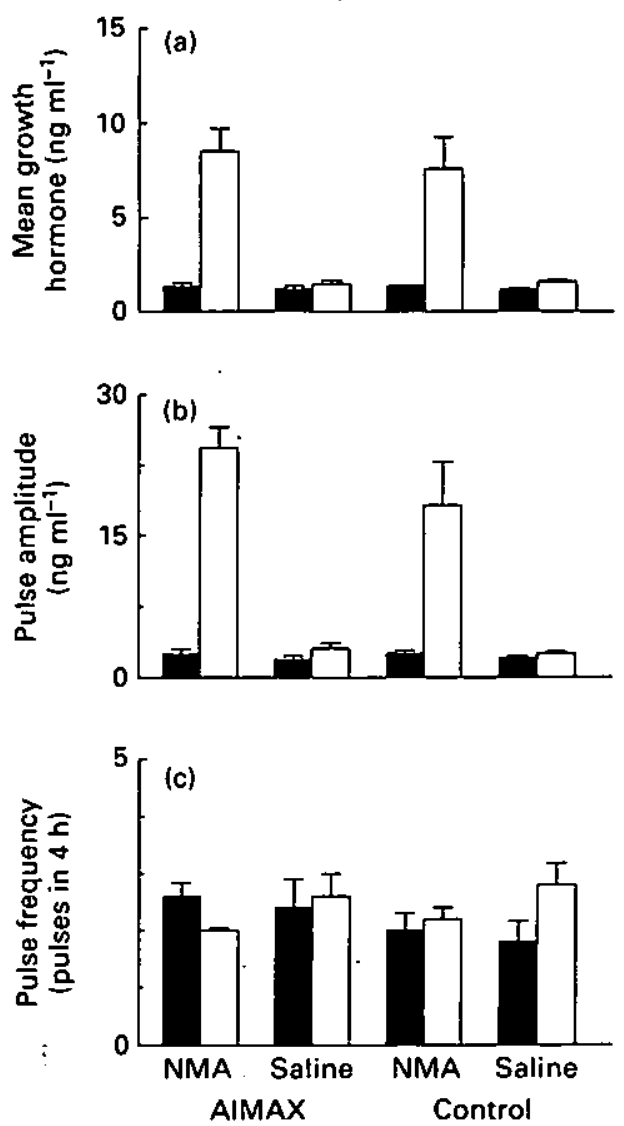

Fig. 4. Mean growth hormone concentrations (a) and the (b) amplitude and (c) frequency of growth hormone pulses in immature boars fed the central catecholamine synthesis inhibitor AIMAX (125 $\mathrm{mg}$ daily for 9 days) or a control diet, and injected intravenously with $N$-methyl-D,L-aspartate (NMA; $2.5 \mathrm{mg} \mathrm{kg}^{-1}$ body weight) or saline. Blood samples were collected every $15 \mathrm{~min}$ for $8 \mathrm{~h}$ and

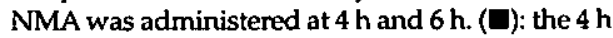
period before NMA or saline injections; ( $\square$ ): the $4 \mathrm{~h}$ period after initiation of NMA or saline injections. Values are means \pm standard errors $(n=5)$. Administration of NMA resulted in an increase $(P<0.01)$ in mean growth hormone concentrations and growth hormone pulse amplitude in both AIMAX-fed and control boars. The frequency of growth hormone pulses was unaffected $(P>0.1)$ by NMA injections.

\section{EXAA as physiological modulators of adenohypophysial hormone secretion}

Although exogenous administration of ExAA alters secretion of adenohypophysial hormones, a physiological role for aspartate and (or) glutamate in control of the hypothalamic-pituitary axis in pigs remains to be determined. If ExAA are involved in physiological control of a particular hormone, then treatment with an ExAA antagonist should have the opposite effect to the ExAA agonist. 

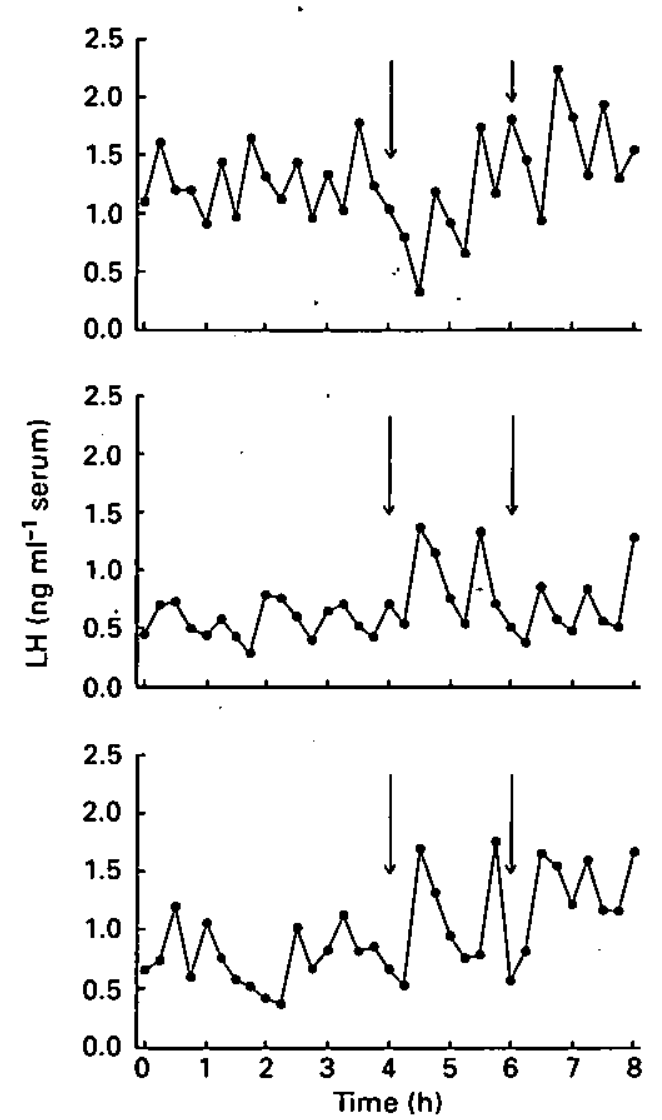

Fig. 5. Serum ' $\mathrm{LH}$ profiles in individual, ovariectomized gilts receiving intravenous injections of the competitive $N$-methyl-Daspartate receptor antagonist $\mathrm{D}, \mathrm{L}-2$-amino-5phosphonovaleric acid (AP5; $13 \mathrm{mg} \mathrm{kg}^{-1}$ body weight). Blood samples were collected at $15 \mathrm{~min}$ intervals for $8 \mathrm{~h}$. AP5 injections were administered at $4 \mathrm{~h}$ and $6 \mathrm{~h}$ and are indicated by the arrows. Frequency of LH pulses was not altered $(P>0.1)$ by AP5 injections. There was, however, a tendency $(P<0.09)$ for LH pulses of greater amplitude after AP-5 treatment.

Experiments during which gonadotrophin secretion was assessed in pigs treated with ExAA antagonists yielded conflicting data. Equivocal results could arise because ExAA neurotransmission may have dichotomous effects on LH secretion. As mentioned earlier, exogenously administered ExAA can both stimulate and inhibit LH secretion. In addition, exogenously administered ExAA and ExAA antagonists may act at different areas of the brain owing to the ability or inability to cross the blood-brain barrier.

Popwell et al. (1996) reported that intramuscular administration of ketamine hydrochloride (20 $\mathrm{mg} \mathrm{kg}^{-1}$ body weight) decreased concentrations of $\mathrm{LH}$ in serum of ovariectomized gilts, a finding consistent with the notion that ExAA are involved in modulating gonadotrophin secretion. In contrast, the frequency of LH pulses was unaltered in a recently conducted experiment during which ovariectomized gilts received intravenous injections of $\mathrm{D}, \mathrm{L}$-2-amino-5-phosphonovaleric acid (AP5), a competitive NMDA receptor antagonist. There was, however, a tendency for greater 


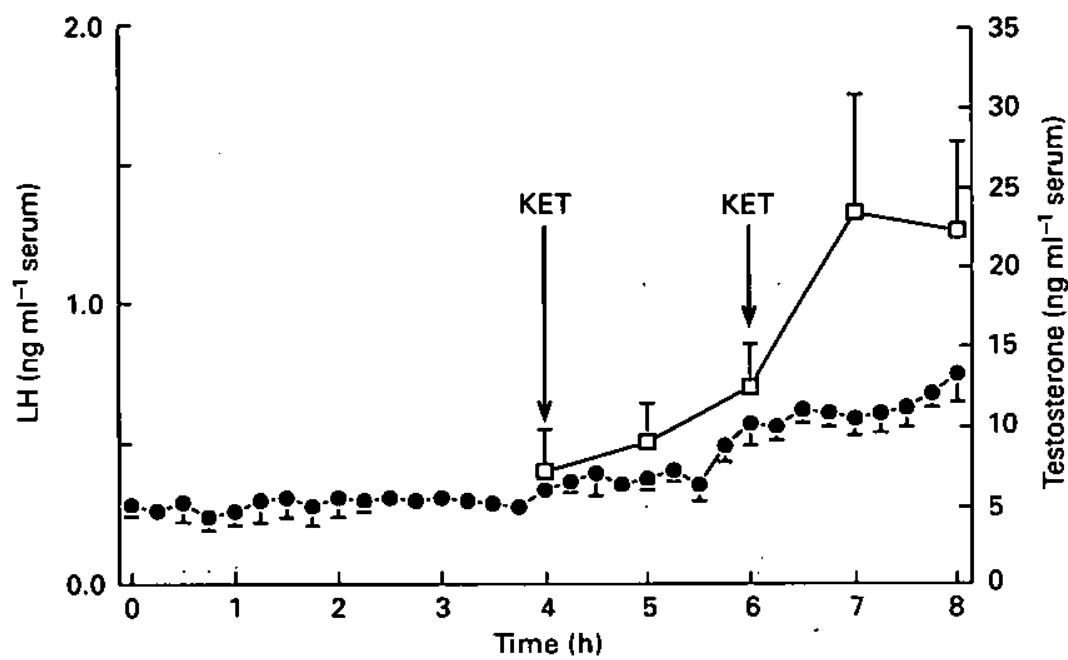

Fig. 6. Serum concentrations of LH (๑) and testosterone $(\square)$ in immature boars receiving intramuscular injections of the noncompetitive $N$-methyl-D-aspartate receptor antagonist ketamine hydrochloride (KET; $19.9 \mathrm{mg} \mathrm{kg}^{-1}$ body weight). Blood samples were collected at $15 \mathrm{~min}$ intervals for $8 \mathrm{~h}$ and KET was administered at $4 \mathrm{~h}$ and $6 \mathrm{~h}$. All samples were analysed for concentrations of LH, and testosterone concentrations were determined in samples collected each hour beginning at $4 \mathrm{~h}$.

, Values are means \pm standard errors $(n=4)$. Administration of KET increased LH $(P<0.01)$ and testosterone $(P<0.07)$ secretion.

amplitude LH pulses after AP5 treatment (Fig. 5; M. J. Estienne, J. M. Harter-Dennis, and C. R. Barb, unpublished). The dose of AP5 used (13 $\mathrm{mg} \mathrm{kg}^{-1}$ body weight) was equimolar to the dose of NMA used previously to stimulate secretion of LH in gilts (Estienne et al., 1995; Hurlock et al., 1995).

We conducted an experiment in which fasted boars, weighing approximately $125 \mathrm{~kg}$ each, were treated intramuscularly with ketamine hydrochloride $\left(19.9 \mathrm{mg} \mathrm{kg}^{-1}\right.$ body weight) or saline (Estienne et al., 1996c). Fasting increased serum concentrations of growth hormone. However, circulating growth hormone concentrations were similar for boars treated with ketamine hydrochloride and saline, suggesting that endogenous ExAA acting via the NMDA receptor are not involved in the physiological control of growth hormone secretion. Interestingly, ketamine hydrochloride increased circulating concentrations of both $\mathrm{LH}$ and testosterone (Fig. 6), a finding consonant with the theory that ExAA inhibit LH release in pigs.

\section{Conclusion}

Evidence has been presented that supports the concept that EOP and ExAA affect secretion of hypothalamic hormones and hence function of the anterior pituitary gland in pigs. In general, EOP inhibit $\mathrm{LH}$ secretion and this effect involves the central catecholaminergic system. A definitive role for EOP in the modulation of FSH release remains to be determined. EOP stimulate secretion of growth hormone and, depending on the animal model studied, EOP exert either a stimulatory or an inhibitory influence on prolactin secretion. ExAA, acting via NMDA receptors, stimulate secretion of LH, FSH, growth hormone and prolactin in appropriate animal models. However, in certain situations an inhibitory effect of ExAA on LH secretion has been demonstrated. The modulation of growth hormone and prolactin secretion by ExAA involves EOP. Research investigating the role of non-NMDA ExAA receptors in the control of adenohypophysial hormone secretion and the function of ExAA in the physiological control of swine reproduction warrant scrutiny. 


\section{References}

Armstrong JD, Esbenshade KL, Coffey MT, Heimer E, Campbell R, Mowles T and Felix A (1990) Opioid control of growth hormone in the suckled sow is primarily mediated through growth hormone releasing factor Domestic Animal Endocrinology 7 191-198

Barb CR, Kraeling RR, Rampacek GB and Whisnant CS (1986a) Influence of stage of the estrous cycle on endogenous opioid modulation of luteinizing hormone, prolactin and cortisol secretion in the gilt Biology of Reproduction 35 1162-1167

Barb CR, Kraeling RR, Rampacek GB and Whisnant CS (1986b) Opioid inhibition of luteinizing hormone secretion in the postpartum lactating sow Biology of Reproduction 35 368-371

Barb CR, Kraeling RR, Rampacek GB and Leshin LS (1987) Opioid modulation of follicle stimulating hormone (FSH) and prolactin (PRL) secretion in the postpartum sow. In Regulation of Ovarian and Testicular Function Pp 647-652 Ed. VB Mahesh, DS Dhindsa, E Anderson and SP Kalra. Plenum Publishing Corporation, New York

Barb CR, Rampacek GB, Kraeling RR, Estienne MJ, Taras E, Estienne CE and Whisnant CS (1988) Absence of brain opioid peptide modulation of luteinizing hormone secretion in the prepubertal gilt Biology of Reproduction 39 $603-609$

Barb CR, Barrett JB, Wright JT, Kraeling RR and Rampacek G8 (1990) Opioid modulation of LH secretion by pig pituitary cells in vitro. Journal of Reproduction and Fertility 90 213-219

Barb CR, Estienne MJ, Kraeling RR, Marple DN, Rampacek GB, Rahe CH and Sartin JL (1991a) Endocrine changes in sows exposed to elevated ambient temperature during lactation Domestic Animal Endocrinology 8 117-127

Barb CR, Kraeling RR and Rampacek GB (1991b) Opioid modulation of gonadotropin and prolactin secretion in domestic farm animals Domestic Animal Endocrinology 8 15-27

Bart CR, Kraeling RR and Rampacek GB (1992a) Opioid modulation of $\mathrm{FSH}$, growth hormone and prolactin secretion in the prepuberal gilt Journal of Endocrinology 133 13-19

Barb CR, Derochers GM, Johnson B, Utley RV, Chang W], Rampacek GB and Kraeling RR (1992b) $\mathrm{N}$-methyl-D,Laspartate stimulates growth hormone and prolactin but inhibits luteinizing hormone secretion in the pig Domestic Animal Endocrinology 9 225-232

Barb CR, Barrett JB, Rampacek GB and Kraeling RR (1993) Nmethyl-D,L-aspartate modulation of luteinizing hormone and growth hormone secretion from pig pituitary cells in culture Life Sciences 53 1157-1164

Barb CR, Chang W], Leshin LS, Rampacek GB and Kraeling RR (1994) Opioid modulation of gonadotropin releasing hormone release from the hypothalamic preoptic area in the pig Domestic Animal Endocrinology 11 375-382

Barb CR, Campbell RM, Armstrong JD and Cox NM (1996) Aspartate and glutamate modulation of growth hormone secretion in the pig: possible site of action Domestic Animal Endocrinology 13 81-90

Bevers MM, Willense AH and Kruip AM (1983) The effect of bromocriptine on luteinizing hormone levels in the lactating sow: evidence for a suppressive action by prolactin and the suckling stimulus Acta Endocrinologica 104 261-265

Broughton DS, Estienne MJ, Harter-Dennis JM and Barb CR (1996) Concentrations of growth hormone $(\mathrm{GH})$ and $\mathrm{LH}$ in serum of boars administered $N$-methyl-D,L-aspartate (NMA) journal of Animal Science 74 (Supplement 1) 91 (Abstract)

Chang WJ, Barb CR, Kraeling RR, Rampacek GB and Leshin LS (1993a) Involvement of the central noradrenergic system in opioid modulation of luteinizing hormone and prolactin secretion in the pig Biology of Reproduction 49 $176-180$

Chang W], Barb CR, Kraeling RR, Rampacek GB and Asanovich KM (1993b) $\mathrm{N}$-methyl-D,L-aspartate modulation of pituitary hormone secretion in the pig: role of opioid peptides Domestic Animal Endocrinology 10 305-313

Chang W], Barb CR, Kraeling RR, Rampacek GB and Wright JT (1995) Biogenic amines in the hypothalamus of rats after diethyldithiocarbamate or AIMAX treatment, an altemative for norepinephrine depletion Joumal of Animal Science 73 1147-1151

De Rensis F, Cosgrove JR and Foxcroft GR (1993) Luteinizing hormone and prolactin responses to naloxone vary with stage of lactation in the sow Biology of Reproduction 48 970-976

Dubreuil P, Pelletier G, Petitclerc D, Lapierre H, Gaudreau P and Brazeau P (1989) Effects of active immunization against somatostatin on serum growth hormone concentration in growing pigs: influence of fasting and repetitive somatocrinin injections Endocrinology 125 1378-1384

Dubreuil P, Couture Y, Pelletier G, Petitclerc D, Delorme L, Lapierre H, Gaudreau P, Morisset J and Brazeau P (1990) Effect of long-term administration of porcine growth hormonereleasing factor and(or) thyrotropin-releasing factor on growth hormone, prolactin and thyroxine concentrations in growing pigs Journal of Animal Science 68 95-107

Esbenshade KL, Ziecik AJ and Britt JH (1990) Regulation and action of gonadotrophins in pigs Journal of Reproduction and Fertility Supplement $4019-32$

Estienne MJ, Kesner JS, Barb CR, Kraeling RR and Rampacek CB (1988) On the site of action of naloxone-stimulated cortisol secretion in gilts Life Sciences 43 161-166

Estienne MJ, Kesner JS, Barb CR, Kraeling RR, Rampacek GB and Estienne CE (1990) Conadotropin and prolactin secretion following intraventricular administration of morphine in gilts Proceedings of the Society for Experimental Biology and Medicine 193 92-97

Estienne MJ, Harter-Dennis JM, Barb CR and Hartsock TG (1995) Luteinizing hormone and growth hormone concentrations in serum of prepubertal gilts treated with $N$-methyl-D, Laspartate Domestic Animal Endocrinology 12 207-213

Estienne MJ, Harter-Dennis JM and Barb CR (1996a) Endocrine responses, growth performance, and carcass quality in domestic animals treated with excitatory amino acids Proceedings 1996 Maryland Nutrition Conference for Feed Manufacturers pp 122-131 Maryland Nutrition Council, College Park, Maryland

Estienne MJ, Harter-Dennis JM, Barb CR, Hartsock TG, Campbell RM and Armstrong JD (1996b) N-methyl-D,L-aspartateinduced growth hormone secretion in barrows: possible mechanisms of action Journal of Animal Science 74 597-602

Estienne M], Harter-Dennis JM and Barb CR (1996c) Modulation of growth hormone $(\mathrm{GH})$ secretion by excitatory amino acids (ExAA) in boars Journal of Animal Science $\mathbf{7 4}$ (Supplement 1) 229 (Abstract)

Hurlock WE, Estienne MJ, Harter-Dennis JM and Barb CR (1995) LH concentrations in serum of gilts treated with $N$-methylD,L-aspartate (NMA) during the estrous cycle or 
following ovariectomy (OVX) Joumal of Animal Science 73 (Supplement 1) 212 (Abstract)

Jayes FCL, Britt JH and Esbenshade KL (1997) Role of gonadotropin-releasing hormone pulse frequency in differential regulation of gonadotropins in the gilt Biology of Reproduction 56 1012-1019

Kesner JS, Kraeling RR, Rampacek GB and Johnson B (1987) Absence of an estradiol-induced surge of luteinizing hormone in pigs receiving unvarying pulsatile gonadotropin-releasing hormone stimulation Endocrinology 121 1862-1869

Kineman RD, Leshin LS, Crim JW, Rampacek GB and Kraeling RR (1988) Localization of luteinizing hormone-releasing hormone in the forebrain of the pig Biology of Reproduction $39665-672$

Kineman RD, Kraełing RR, Crim JW, Leshin LS, Barb CR and Rampacek GB (1989) Localizätion of proopiomelanocortin (POMC) immunoreactive neurons in the forcbrain of the pig Biology of Reproduction 40 1119-1126

Klindt J, Ford JJ, Berardinelli JG and Anderson LL (1983) Growth hormone secretion after hypophysial stalk transection in pigs Proceedings of the Society for Experimental Biology and Medicine 172 508-513

Kraeling RR, Rampacek GB, Cox NM and Kiser TE (1982) Prolactin and luteinizing hormone secretion after bromocryptine (CB-154) treatment in lactating sows and ovariectomized gilts Journal of Animal Science 54 1212-1220

Kraeling RR, Kesner JS, Estienne, MJ, Estienne CE, Barb CR and Rampacek GB (1990) Follicle growth in hypophysial stalktransected pigs given pulsatile GnRH and pregnant mares' serum gonadotropin Domestic Animal Endocrinology 7 395-402

Kraeling RR, Batb CR, Leshin LS and Rampacek GB (1992) Central nervous system peptide and amino acid modulation of luteinizing hormone and prolactin secretion in the pig Journal of Physiology and Pharmacology 43 (Supplement 1) 79-103

Kraeling RR, Estienne MJ, Barb CR and Rampacek GB (1994) Prolactin secretion after bromocryptine in the hypophysial stalk-transected gilt Life Sciences 54 1681-1685

Leshin LS, Kraeting RR, Barb CR and Rampacek GB (1992) Associated luteinizing hormone-releasing hormone and luteinizing hormone secretion in ovariectomized gilts Domestic Animal Endocrinology $977-88$

Leshin LS, Barb CR, Kiser TE, Rampacek GB and Kraeling RR (1994) Growth hormone-releasing hormone and somatostatin neurons within the porcine and bovine hypothalamus Neuroendocrinology 59 251-264

Leshin LS, Kraeling RR, Kineman RD, Barb CR and Rampacek GB (1996) Immunocytochemical distribution of catecholaminesynthesizing neurons in the hypothalamus and pituitary gland of pigs: tyrosine hydroxylase and dopamine- $\beta-$ hydroxylase foumal of Comparative Neurology 364 151-168
Lutz JB, Rampacek GB and Kraeling RR (1985) Induction of ovulation in the prepuberal gilt by pulsatile administration of gonadotropin releasing hormone Domestic Animal Endocrinology $261-65$

Mattioli M, Conte F, Galeati G and Seren E (1986) Effect of naloxone on plasma concentrations of prolactin and $\mathrm{LH}$ in lactating sows Journal of Reproduction and Fertility 76 $167-173$

Parvizi $N$ and Ellendorff $F$ (1982) Further evidence on dual effects of nonepinephrine on LH secretion Neunoendocrinology 35 48-55

Patchev V, Parvizi N and Ellendorff F (1987) Naloxone effects on luteinizing hormone secretion in immature male pigs: an androgen independent process Neuroscience 22 (Supplement 1) 5156 (Abstract)

Petralia RS and Wenthold RJ (1996) Types of excitatory amino acid receptors and their localization in the nervous system and hypothalamus. In Excilatory Amino Acids: Their Role in Neuroendocrine Function PP 55-101 Ed. DW Brann and VB Mahesh. CRC Press, Boca Raton, Florida

Popwell JM, Estienne MJ, Kraeling RR, Barb CR, Whitley NC, Utley RV and Rampacek GB (1996) The role of excitatory amino acids in pulsatile secretion of luteinizing hormone in gilts and barrows Journal of Animal Science 74 10671073

Price MT, Olney JW, Lowry OH and Buchsbaum S (1981) Uptake of exogenous glutamate and aspartate by circumventricular organs but not other regions of brain Journal of Neuracizemistry 36 1774-1780

Sesti LAC and Britt JH (1992) Elicitation of release of luteinizing hormone by $\mathrm{N}$-methyl-D, L-aspartic acid during three paradigms of suppressed secretion of luteinizing hormone in the female pig Domestic Animal Endocrinology 9 105-114

Sesti LAC and Britt JH (1993) Agonist-induced release of gonadotropin-releasing hormone, luteinizing hormone, and follicle-stimulating hormone and their associations with basal secretion of luteinizing hormone and folliclestimulating hormone throughout lactation in sows Biology of Reproduction 49 332-339

Sesti LAC and Britt JH (1994) Secretion of gonadotropins and estimated releasable pools of gonadotropin-releasing hormone and gonadotropins during establishment of suckling-induced inhibition of gonadotropin secretion in the sow Biology of Reproduction 50 1078-1086

Trudeau VL, Meijer JC, van de Wiel DFM, Bevers MM and Erkens JHF (1988) Effects of morphine and naloxone on plasma levels of LH, FSH, prolactin and growth hormone in the immature male pig Journal of Endocrinology 119 501-508

Trudeau V, Pharazyn A, Beltranena E and Aheme FX (1989) Naloxone elevates plasma follicle stimulating hormone but not luteinizing hormone levels in the immature male pig Canadian Journal of Animal Science 69 1095-1098 